\title{
LEGAL CERTAINTY VERSUS EQUITY IN THE CONFLICT OF LAWS ${ }^{\dagger}$
}

\author{
Paul Heinrich Neuhaus*
}

\section{INTRODUCTION}

The struggle between legal certainty and equity is as old as the law itself. Only the labels have changed: while formerly discussion proceeded in terms of ius strictum and ius aequum, the expressions currently preferred, especially in Germany, are "legal certainty" and "justice (in individual cases)." Whatever terms are used, they refer to two different aspects of the law. One is the public interest in clear, equal, and foreseeable rules of law which enable those who are subject to them to order their behavior in such a manner as to avoid legal conflict or to make clear predictions of their chances in litigation. The other is the need for deciding current, concrete disputes adequately, by giving due weight to the special and perhaps unique circumstances of each case. The former aspect calls for legislation, the latter for judicial decision.

It has often been said that legislation corresponds to the abstract and systematic mode of thought of continental Europeans, while judge-made law is more suited to the practical and empirical style of Britons and Americans. Indeed, in England as well as in the United States, even statutes are generally directed not so much to general regulation in comprehensive terms, but rather to case-by-case solutions of separate situations. It is for this reason that a German lawyer who had just written a report on the latest English legislation, complained that when compared with English statutes, the labyrinth of Minos would look like a formal garden. ${ }^{1}$ On the other hand, continental judges are so accustomed to decide not on the basis of precedents but on that of general statutes that they incline to express their own decisions in general terms resembling the style employed in legislation. Thus, the German Supreme Court once remarked, with respect to public policy:2

Although the question as to the compatibility of the application of a rule of foreign law with the purposes of our legislation cannot be decided in an abstract manner but only in accordance with the circumstances of each individual case, still the decision of the individual case must be based on a rule which, when generalized, deserves approval.

tAuthorized translation from the German by the Editor.

- Dr. rer. pol. Münster (1939); Dr. iur. Tübingen (1945). Research Associate, Max-Planck-Institut für ausländisches und internationales Privatrecht, Hamburg; Academic Member, Max-Planck-Gesellschaft; Honorary Professor of Law, University of Hamburg.

${ }^{1}$ Letter of Hans A. Schwarz-Liebermann von Wahlendorf to the author, accompanying the manuscript of Schwarz-Liebermann \& Daig, Die englische Gesetzgebung auf dem Gebiete des Privatrechts 1945-1950, 17 Rables ZeItschirift für aUsL Ändisches UND internationales Privatrecht [hereinafter cited as RABELSZ] 56 (1952).

8 Entscheidungen des Reichsgerichts in Zivilsachen 129, 132-33 (I9r2). Cf. Swiss CrviL Code art. I, $\$ 2$ : "If the Code does not furnish an applicable provision, the judge shall decide ... according to the rule which he would establish as legislator" (English translation in Rudolf B. Schlestnger, Comparative LAW 3 I8 (2d ed. I959)). 
On the other hand, this difference between the civil law ${ }^{3}$ and the common law (i.e., the preference of the former for general statutes serving legal certainty, and the emphasis of the latter on judicial decisions purporting to do justice to the individual circumstances) should not be exaggerated. For instance, ancient Roman law, the root of all continental legal systems, was primarily case law. On the other hand, American law is partly based on continental European canon law and on regional codifications; furthermore, there is the stabilizing effect of stare decisis. Especially in recent times, civil law and common law have come closer to each other. On the continent, judicial decisions have constantly gained in importance as against the codes, which are more and more recognized to be full of gaps and which are partially outmoded. Recently, an Austrian author, in a much noticed book entitled From the Legislative to the Judicial State, has deduced by purely philosophical and systematical considerations the superiority of judge-made law to legislation. ${ }^{4}$ And on the other side of the Channel and of the Atlantic, judge-made law is frequently replaced by statutes. At least the gap between present-day German and American legal method is much smaller than that between English and French or Italian law. ${ }^{\sigma}$ Furthermore, the geographical (horizontal) differences are substantially mitigated in significance by (vertical) movements in time. Just as there are parallels between the epochs of European and American cultural history since the Enlightenment, there have been many similarities in the history of law on both sides of the Atlantic; and we may well expect the intensification of economic and political ties between the two continents to contribute to a further synchronization of the respective legal systems.

But the conflict between legal certainty and justice (equity) will never come to an end. In different countries and at different times, the one or the other of these twin objectives of the law will dominate; there is no permanent solution. Especially neither goal can replace the other. Thus, it cannot be maintained that real legal certainty is the certainty that justice will prevail ${ }^{6}$-just as there is no merit to the assertion that in some technical branch of the law (e.g., civil procedure) the sole purpose of justice is to guarantee the certainty of the law.

All that has been said above also applies to the conflict of laws. In this area as well, legal certainty and justice are struggling for supremacy; and the predominance of the one over the other differs in point of time as well as place. In the following, an attempt will be made to show how in our century, the trend (in Europe somewhat earlier than in America) was from the predominance of legal certainty to the

"As herein used, "civil law" or "continental European law" does not include the law of the communist states. The to some extent quite different problems arising in connection with the latter cannot be discussed within the scope of this article.

¿ Rente Marcic, Vom Gesetzesstaat zum Richterstant especially $231-52$ (1957).

'See Rabel, Deutsches und amerikanisches Recht, I6 RABELsZ 340, 342, 349 (1951), rcferring to German and American law as "the most telling examples of modern progressive development" and showing by several examples "how closely related the trends are today in Germany and in the United States."

- This was claimed by Hermann Göring in his speech, Die Rechtssicherheit als Grundlage der Volksgemeinschaft, I Zetrschrift deR AKADEMIE Für Deutsches Recht 233 (I934). 
emphasis on justice, and how today, at least in Europe, there is once more a signifcant tendency in favor of certainty in the law. It is, of course, impossible to write a full modern history of private international law in this paper. We have to limit ourselves to mentioning some typical points of the development, and will not always be able to avoid seemingly perfunctory observations.

\section{The Predominance of Certainty}

At the beginning of the twentieth century, the idea of certainty of the law was in its heyday. While the natural sciences, philosophy, and the fine arts were already in various stages of rebellion against the dominant ideas of the last century, legal theory continued to reflect the constancy of economic development and international peace which existed until Igr4-at least so far as Western Europe and America are concerned. There was little cause for a re-examination of traditional modes of thought. The promotion of legal certainty with a view to eliminating the legal risks of business and of other transactions by making them clearly predictable was regarded more important than the struggle for justice and for equity, which were largely not considered to be in danger, anyway. Even after World War I, the tendency towards legal certainty continued to be dominant in many instances. To a large extent, this was probably due to two reasons. First, many persons were inclined to ignore, as much as possible, the basic transformation of their environments, and to return to the old standards (e.g., the gold standard) as soon as practicable. Secondly, lawyers often consciously tend to oppose revolutionary change and to defend traditional values (a typical example is the preparatory work that went into the Italian Civil Code of 1942; here, the Italian legal profession defended the traditional legal doctrines of nineteenth century liberalism against revolutionary fascism ${ }^{7}$ ). In the field of private international law, the strong predilection for legal certainty is apparent in the point of departure (A), in the method adopted (B), and, finally, in the objective sought $(\mathrm{C})$.

\section{A. The Point of Departure}

The conflicting schools of private international law at the turn of the centuryinternationalists, nationalists, adherents of the theory of "vested rights," proponents of domicile or nationality, partisans and enemies of renvoi, and so on-ail proceeded from certain general principles (e.g., comity, national sovereignty, global renvoi) from which they attempted to deduce their theses with compelling logic. This applies not only for the realm of the civil law, but for English and American authors as well. The internal consistency and the consequent clarity of the various theories appeared to be more important to their proponents than mere practical considerations.

${ }^{7}$ See Neuhaus, Das internationale Privatrecht im italtenischen Zivilgesetzbuch von 1942, I5 RABELSZ 22, 32 (1949). 


\section{B. The Method}

The formal fixing of choice-of-law rules by statutes or-preferably-by international agreements was regarded as the method best suited to increase legal certainty in this area. Especially the attempts at the international unification of conflict-oflaw rules undertaken by the Hague Conference on Private International Law, which convened four times between 1893 and rgo4, were accompanied by great optimism in this regard. The theoretical groundwork for the Hague Agreements was laid to a large extent by the guidelines and drafts elaborated by the Institut de Droit international (since 1873) which included Anglo-American lawyers ever since its establishment, and by the International Law Association which was established through American initiative.

\section{The Goal}

At the beginning of this century, the highest aim of conflict-of-laws rules, and the specific objective of international agreements, was considered to be the guaranteeing of the uniformity of decisions. Friedrich Carl von Savigny had already described this ideal to be "that, in cases of conflict of laws, the same legal relations (cases) have to expect the same decision, whether the judgment be pronounced in this state or in that"; he had spoken of "the desirable and gradually approaching accord in deciding cases of conflict in different states." Franz Kahn coined the term, "harmony of laws" ("Gesetzesharmonie")"; Dicey and Pillet preferred a more subjective expression for the same ideal: protection of "duly acquired rights"10 or of "droits acquis."11

\section{II}

\section{Transition Towards Equity}

The political, economic, and social changes brought about by two world wars have had some influence on legal thinking, as had the progressive influence of the methods of the natural sciences. On the one side, the quest for security and continuity had to make room for attempts to attain a new equity. For when confronted with massive currency depreciations, the principle of pacta sunt servanda lost its absolute effectiveness; the idea of the completeness of existing legal orders was destroyed and numerous gaps were revealed by confrontation with a world which was undergoing drastic changes; and in the face of a lawgiver who himself was a criminal, it could no longer be maintained that even the worst law was better than rebellion because it provided at least for an orderly state of affairs. On the other

\footnotetext{
8 Friedrich Cart von Savigny, System des heutigen Römischen Rechts 27 and 129 (1849); the English translation here used is William Guthrie, Private International. Law, and the RetroSpective Operation of Statutes 69-70 and 145 (2d ed. 1880).

- Kahn, Gesetzeskollisionen (1891), reprinted in I Franz KaHN, AbHandzuncen zum intrrnationalen Privatrecht at 122 (1928).

${ }^{10}$ Albert Venn Dicey, a Digest of the Law of England with Reference to the Conflict op LAWS 22 ( 1896 ) (General Principle no. I).

11 antoine Pillet, Principes de droit international prive 33-34 (ig03).
} 
side, a more sociological and realistic attitude towards the law led to increased awareness of the law in action ("Rechtstatsachen") and of relevant interests instead of abstract terms.

Private international law did not remain unaffected by these changes. Again, we shall distinguish between the point of departure, the method, and the objective.

\section{A. The Point of Departure}

Instead of rigid principles, the modern authors of private international law cultivate a realism that is free from ideologies, and a sober respect for actual circumstances and interests-especially for the purpose of the rules of substantive law which are ultimately at issue. A critical analysis of judicial decisions with a view to discovering the real reasons hidden behind conventional opinions is much in vogue, as evidenced, for instance, by the discovery of the "homeward trend."12 In the preparation of statutes and of international agreements, the national interests affected are disclosed point blank. Thus, immigrant countries favor the domicile principle for questions of personal status and relations in order to assimilate immigrants who still retain their old nationality, and to keep them from becoming a foreign-law based state within the state. ${ }^{13}$ Countries of emigration, on the other hand, choose the nationality principle, asserting that the emigrants want to retain their ties to their homeland even when abroad. ${ }^{14}$ Furthermore, in a debtor state, it is suggested that the personal law of the debtor should govern loan contracts, because this will lead to the more frequent application of the lex fori. ${ }^{15}$ German authors speak of "internationally typical interests," of interests" in private international law. ${ }^{17}$ In the United States, a large portion of learned comment deals with the question as to which state has the predominant interest in the application of its laws to various fact situations. The doctrinal dispute as to the nature of the applicable foreign law between the adherents of the "fact" and the "law" theories loses its significance because the several questions relating to pleading, proof, and application of foreign law (judicial notice or proof by the parties; determination by the judge or by the jury; reviewability on appeal or cassation) are increasingly decided not in accordance with a paramount principle, but with a view to procedural convenience and expediency. ${ }^{18}$

22 The term was coined by Arthur Nussbaum, Deutsches internationales Pruvatrecht 43 (I932); see also Arthur Nussbaum, Principles of Private International Law 37 (1943).

${ }^{23}$ Joint Declaration of the delegates of Colombia and Costa Rica at the signing of the Código Bustamante, Sexta Conferencia Internacional Americana, Acta final 83 (I928).

24 See, for instance, Maridakis, Les principaux traits de la récente codification hellénique touchant le droit international privé, 85 Académie de Droit International, Recueil des Cours I0\%, 159 (1954-I): "The Greek, wherever he may be, has only one dream: to return and to hear again the bell of the humble church of his hamlet" (translated from the French by the Editor).

${ }^{10}$ This suggestion is made in the Official Explanation of draft Hungarian Statute on Private International Law (r947) (not published; quoted in Paul Heinrich Neuhaus, Die Grundbegriffe des Internationalen Privatrechts 36 n.82 ( 1962 )).

${ }^{20}$ Zweigert, Nichterfiillung auf Grund ausländischer Leistungsverbote, 14 RABELsZ 283, 291 (1942).

${ }^{17}$ Especially Kegel, Begriffs- und Interessenjurisprudenz im internationalen Privatrecht, FESTsCHRIFT Hans Lewald 259 (1953); cf. Gerhard Kegel, Internationales Privatrecht 28 et seq. (1960).

${ }^{18}$ Sec, e.g., Dölle, Über die Anwendang fremden Rechts, [1957] GewERBLICHER RechtsschuTz UND 


\section{B. The Method}

In the period of transition from certainty to equity, the most popular path pursued by private international lawyers no longer leads to codification and to the, conclusion of treaties. While there still are some codifications, these are not representative of the new era, but rather stragglers from times past. ${ }^{10}$ Most of the newer multilateral agreements are not ratified. ${ }^{20}$ It is even suggested, on occasion, that existing laws be repealed and everything be left to adjudication. ${ }^{21}$ Courts as well as academic authors prefer elastic formulae such as "the proper law," "the spatially closest law," "grouping of contacts," and "center of gravity," and neglect fixed choice-of-law rules. It is explicitly pointed out that the decisions of conflictof-law cases by mechanized rules have not even promoted certainty and uniformity. ${ }^{22}$ Indeed, it is the very fact that these rules often lead to inequitable results that militates against their gaining general recognition. A European author even says that the difficulties facing private international law are "so complicated and so extensive that it is completely impossible to draft general rules... in anticipation of conflicts." And an American commentator asserts repeatedly: "We would be better off without choice-of-law rules."24

In more concrete terms, the fixed connecting factors of nationality or domicile are frequently replaced by "domicile in fact" (résidence habituelle). Especially nationality as a connecting factor is abandoned wherever it would lead to unjust decisions: for instance, with respect to refugees who are nationals of their countries of origin in form only; ${ }^{25}$ to spouses of different nationality but common domicile; ${ }^{20}$

URHEBERRECHT 56; Schlesinger, Die Behandlung des Fremdrechts im amerikanischen Zivilprozess, 27 RABELSZ 54 (1962).

${ }^{10}$ E.g., the Polish law of 1926 and the Czechoslovak law of 1948 , both of which are based on an Austrian draft of 1913; articles 17-31 of the Disposizioni sulla legge in generale of the Italian Civil Code of 1942 , see Neuhaus, supra note 7, especially at 34-35; and the to some extent quite similar articles 5-33 of the Greek Civil Code of 1940 , see Gogos \& Aubin, Das Internationale Privatrecht im griechischen Zivilgesetzbuch von 1940, 15 RABELSZ 240, especially 247 (1949). All legislative texts may be found, in German and French translations, in Alexander N. MARarov, Quellen pes Intrernationalen Privatrechts (2d ed. I953 et seq.).

${ }^{20}$ E.g., the agreement for the enacting of a uniform statute on private international law in the Benelux states, signed on May II, 195I. Of the eight Hague Agreements on Private International Law drafted in the fifth through ninth sessions in The Hague (1925-1960), only one agreement was in force as of April $x, 1963$, and that only as between 5 of the 18 Member States of the Conference. Note, Conférence de La Haye de droit international privé, Etat actuel des travaux, 52 Revue CRITiQue DE DROIT INTERNATIONAL PRIVÉ 138, with tables at 139-4I (1963).

${ }^{21} \mathrm{See}$, with respect to Austria, Wahle, Book Review, 12 Österreichische Jurusten-Zeitunc 6r4, 615 (1957).

22 See Judge Frank in Siegelman v. Cunard White Star Ltd., 221 F.2d I89, 206 (2d Cir. 1955), observing, in reliance upon writings by Cavers, Rheinstein, and Goodrich: "It is generally agreed that the decisions of conflict-of-laws cases by mechanized rules... cannot be defended on the ground that they have promoted certainty and uniformity, since such results have not been thus achieved."

${ }^{23}$ Georg Cohn, Existenzialismus und Rechtswissenschaft 19 (1955).

${ }^{24}$ Currie, Notes on Methods and Objectives in the Conflict of Latus, I959 Duke L.J. I7I, I77; Curric, The Verdict of Quiescent Years: Mr. Hill and the Conflict of Laws, 28 U. CH1. L. Rev, 258, 259 (1961).

${ }^{25}$ Especially article 12 of the Geneva Convention of July 28, 195I, Relating to the Status of Refugees, 189 U.N.T.S. I50.

${ }^{30}$ See, e.g., the famous decision of the French Cour de cassation in the Rivière case, 42 RevuB CRITIQUe DE DRoIT INTERNATIONAL PRIVÉ 4T2 (1953) with note Batiffol and 20 RABelsZ 519 (I955) with note Francescakis. 
and to the support claims of children not residing in the country of their nationality. ${ }^{27}$ The principle of the "immutability" of the regime of matrimonial property is rejected because the necessity of blending in with changed circumstances is thought to outbalance the difficulties of changing the matrimonial property regime during coverture. $^{28}$ The applicability of foreign conflict-of-laws rules and the relevance of party autonomy are not rejected out of hand as illogical, but appropriate solutions are sought for each distinctive fact pattern. Foreign conflict-of-laws rules are taken into consideration especially when the international recognition or effectiveness of a judicial decision is dependent upon them. ${ }^{29}$ Party autonomy is fully recognized except in cases of evasion of statutes or other instances of abuse. Ordre public or public policy, one of the fundamental principles of private international law according to the Franco-Italian theory, metamorphoses into an escape valve for particularly unusual foreign law even in France and Italy; and the "relativity" of public policy is frequently emphasized.

\section{The Goal}

The goal of choice-of-law rules in more recent days appears to be not the international harmony of decisions but the best substantive solution of all cases-the appropriate decision in terms of substantive law. There is direct talk of a "resultselective approach." 30 The judge is to apply the "more progressive" or the "better" substantive law in case of doubt, and generally to take into account the "policy" of his state; the latter notion far transcends the most extreme theory of ordre public. When parts of different legal orders are applicable to a set of facts, it is suggested that the judge avoid an unjust decision through a process of discretionary "adaptation," the outcome of which cannot be predicted. ${ }^{31}$

Generally speaking, there appears to be a crisis in private international law, for both the possibility and the willingness to apply foreign law have decreased as a consequence of the enhanced importance of normative legal principles and of general clauses. $^{32}$ It is pointed out again and again that the application of foreign law is not the only means for the approximate solution of "international" fact situations. Traditional choice-of-law rules ("Verweisungsrecht") are challenged by a new issue:

${ }^{37}$ Especially the Hague Convention on the Law Applicable to Obligations to support Minor Children, of Oct. 24, 1956, 5 AM. J. CoMp. L. 656 (1956).

${ }^{28}$ Sec, e.g., the recommendation of the Commission on Family Law of the German Council on Private International Law, in VoRschläGE UND GUTACHTEN zUR REForM DES DEUTSCHEN INTERNATIONALEN Eherechts 2-3 (1962) (comment, id. at 22), also reprinted in 25 RabelsZ 340 ( 1960 ); cf. Kegel, Reform des deutschen internationalen Eherechts, id. at 201, 208.

${ }^{20}$ The leading article on this subject was Melchior, Die Selbstbeschränkung des deutschen internationalen Privatrechts, 3 RABELsZ 733 (1929).

${ }^{30}$ Hancock, Three Approaches to the Choice-of-Law Problem, XXTH Century Comparative and Conflicts Law (Legal Essays in Honor of Hessed. E. Yntema) 365 (Ig6r).

${ }^{31}$ See especially Lewald, Règles générales des conflits de lois, 69 Academie de Droit InternationaL, Recuell des Cours I, I36-45 (I939-III); Jochen Schröder, Die ANpassung von Kollisions- und Sachnormen (r96I); and, with respect to the latter, Neuhaus, Book Review, 26 RabelsZ 753 (196r).

${ }^{32}$ For details, see Neuhaus, Die Krise im internationalen Privatrecht, 3 Deutsche Rechts-ZeItschrIFT 86 (1948); cf. Neuhaus, op. cit. supra note 15, at 18-20. 
decisional law ("Entscheidungsrecht") which regulates these fact situations directly ${ }^{33}$ -and not only in the shape of internationally uniform rules, i.e., a "private law on the international level, ${ }^{34}$ but also in the form of a purely national body of separate rules for the decision of cases with foreign elements.

\section{III}

\section{The New Search for Legal Certainty}

Perhaps the tendency of subordinating legal certainty to justice in individual cases has not as yet reached its peak; and legislation as well as adjudication still frequently continue to employ the traditional, rigid formulae. But in some places, there already appears again a reversion (or, rather, a new progress) towards a novel kind of legal certainty; and it is the most important aim of the present paper to call attention to this new trend. Again, the political and economic development of the leading countries may have been decisive. A certain stabilization after the changes and disturbances wrought by World War II and its immediate aftermaths; the integration of Europe and, generally, of the free world; and finally, increasing contacts with underdeveloped countries-these are the factors that may contribute today or in the near future to strengthening the quest for legal certainty. But the real reasons go deeper: the search for certainty in the law is an essential function of law as such, and therefore cannot be suppressed for any length of time.

\section{A. The Point of Departure}

While the past started from more or less abstract principles and the present regards the relevant interests as most significant, the lawyer of the future will have to devote his chief attention to generally recognized values or standards. A radical "jurisprudence of interests" is revealed to be logically deficient and impracticable once it is realized that the interests in conflict cannot always be quantified but often are of different quality, so that a choice between them requires a value judgment. (Even "interests" is prone to be a misleading label, for it tends to falsify this value judgment by an overemphasis of the material and otherwise tangible interests and a corresponding neglect of higher, spiritual values.) In a democratic and pluralist society, the standards for judgment cannot be purely personal or irrational; the judge must be guided by generally recognized standards capable of rational cognition. This is the essential difference between a democratic legal order and a so-called Khadi justice which decides individual cases in accordance with the judge's sense of equity and without reliance on any objective standards. ${ }^{35}$ The practical need for

${ }^{33}$ The term was coined by Dölle, Gegenwärtige Aufgaben der deutschen Wissenschaft vom internationalen Privatrecht, Deutsche Rechts-Zeitschirif, Supplement 5, p. 3, at 5 n.Io (1948). In

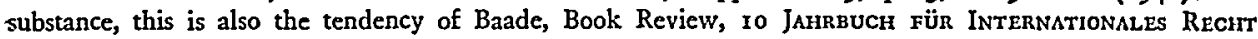
$330(1962)$.

${ }^{34}$ The expression was coined by Rabel, Privatrecht auf internationaler Ebene, UM RECHT UND Gerechtigkeit (Festgabe für Erich KaufmanN) 309 (I950).

${ }^{85}$ For a discussion of Khadi justice, see 2 Max Weber, Wirtschaft und Gesel.sschaft 571 (4th ed. Johannes Winckelmann, I956); also the English translation of MAx RHEINSTEIN, MAx Weder oN LAW IN ECONOMY AND SOCIETY 351 (1954): it "decides cases...non-formalistically and in accordance with concrete ethical or other practical value-judgments; ....there are no 'rational' bases of 'judgment.' " 
uniformity and predictability of decisions and the dignity of the individual, which is incompatible with arbitrary judicial flat, create an abiding need for objective standards of law.

Whether these standards are contained in laws or in precedents, in constitutions or in international declarations of the rights of man, is a matter of subsidiary importance. The main thing is that the judge must be able to find the answer to the question not yet specifically provided for by discovering the spirit and the purpose of those texts through taking into consideration the interaction of their various norms. It is the special task of the science of the law to bring out these interactions between individual legal norms. The method required for this task will continue to be the development of clear terms and the construction of a system. This does not imply a return to antiquated notions of analytical jurisprudence, or Begriffsjurisprudenz, for terms and construction now have a different significance. The past has made us suspicious of a purely logical-deductive and stationary approach to terminology and systematic analysis. The development and the adaptable application of the law must remain possible in a changing world, and each value judgment must proceed from an exact analysis of the facts. But despite the myriad of actual fact situations and possible points of approach to the decision of concrete cases, the lawyer should always strive to express the solution of individual cases in clear terms, and seek to fit them into a larger framework. In Ernst Rabel's words, there should be "system construction from below."36

As regards our field, the conflict of laws, there are two reasons for thinking that firm standards that help to avoid confusion and arbitrary actions are especially needed here. First, the judge himself needs such standards. For a choice-of-law problemthe question as to the law to be applied and as to the rules for its application-incites so little spontaneous legal reaction and occurs so seldom in the experience of most lawyers that a judge will be relatively helpless when faced with these complicated problems, and will have to obtain guidance from clear rules if he is to avoid decision by chance. Secondly, in transnational controversies, the parties are particularly dependent upon the service of attorneys and judges, for they often live under different legal systems and therefore have no common legal or extra-legal customs and expectations. While in internal law, a legal reference to "good faith" or to the "custom of trade" will occasionally suffice, private international law always requires more precise rules. It is therefore a matter of profound regret that some authors become the victims of a certain "pointillisme" that recommends decisions which vary from case to case (or even from edition to edition) without supplying either solid paths for the courts or a guideline to students. ${ }^{37}$ And above all, lawyers should avoid the appearance of surrendering to the power of the stronger party or state, and of seeing their function in the mere "transformation of power into law."38

${ }^{\text {sa }}$ Rabel, Die Faclagebiete des Kaiser Wilhelm-Instituts fïr ausländisches und internationales Privatrecht 1900-1935, 325 JAhre Kaiser Wilhelm-Gesellschaft 77, 109 (1937).

${ }^{37}$ Batiffol, Book Review, 48 REvuE CRITIQUe DE DROIT INTERNATIONAL PRIVE 775,777 (1959).

${ }^{38}$ See the criticism of Kollewijn against this misleading formula, Book Review, 7 NEDERLANDs Tijpschrift voor International Reicht 384, 385 (Ig6o). 


\section{B. The Method}

Between the extremes of rigid general rules and the lack of any rules, there is a middle way (unfortunately, it is not superfluous to state such a triviality). This middle way consists of refined and elastic rules that provide for specified solutions for different types of cases and also allow for exceptions in special situations. Thus, already in 1908, the Institut de Droit international resolved that the proper law of contracts be determined by a catalogue of choice-of-law rules for specific types of contracts, and by a supplementary general clause. ${ }^{39}$ Similarly, in more recent times it was recommended that the choice of law in torts be diversified by adding to the traditional rule (applicability of the lex loci delicti commissi) a general clause for exceptional circumstances as well as a catalogue of choice-of-law rules for typical cases. ${ }^{40}$ There might be dispute over the relative importance of the general rule, the escape clause, and the detailed rules for typical transactions or events. But in any case, there is no need for doing away with definite rules altogether, so long as the various rules are not simply derived from abstract notions such as contract and tort, but are based on a comparative legal analysis of different kinds of typical events and relations. ${ }^{41}$

However, such a differentiation becomes problematical where a series of relationships in actual life are loosely interconnected, as for instance in the area of family law and succession. The form of marriage as well as its personal and property effects, parentage, relations of parents to legitimate and illegitimate children, divorce, and the order of succession are always somehow interrelated. Yet it appears impossible to subject the personal and family affairs of a man from cradle to grave, or yet all legal interrelations of an entire family, always to the same law. This observation holds true as regards the three distinct relationships involved in a guarantee contract or the old and the new contractual relationship in the case of a novation. Here it is often possible to create choice-of-law rules for the various facets of the basic relationship which, while not identical, are nevertheless similar and will in many cases lead to the application of the same legal order. At least, it should not be left entirely to the discretion of the judge who chances to hear his case to determine the "proper law of a person." Quite to the contrary, there always should be a careful effort not to destroy unnecessarily a more comprehensive relationship by an overrefined ad hoc analysis of that facet which happens to be at issue.

On the positive side, the need for prudent differentiation is well illustrated by a recurring problem of transnational contracts law. Here, it is increasingly realized that choice-of-law rules for economic-regulatory law (including currency control

\footnotetext{
38 22 ANnuAtre de L'INSTITUT de Drott international 289-92 (1908); sec in this connection Makarov, Die Resolution des "Instizut de Droit international" ïber das internationale Obligationenrecht sund deren Einfluss auf die nationalen Kodifikationen des Kollisionsrechts, FESTSCHRIFT HaNs Leward 299 (1953).

${ }_{10}$ Binder, Zur Auflockerung des Deliktsstatuts, 20 RabelsZ 401, 498-99 (1955).

${ }^{21}$ Rabel, Das Problem der Qualifikation, 5 RABELSZ 241, 258 (1931): "There is a healthy and promising tendency towards discovering inductively the choice-of-law rules which are appropriate to each individual legal type."
} 
and antitrust) cannot be identical with the rules determining the law of the contract itself. ${ }^{42}$ For these rules transcend the conflicts law of private contracts which is based on the principle of freedom of contract and the search for the "proper" law, and lead into the realm of public law where considerations of "policy" are more relevant. It would be just as unreasonable to let the parties choose their own currency control law as it would be to determine rules for the protection of private interests (e.g., the permissibility and the extent of contractual limitation of liability) in accordance with the "interests" of the enacting state and to apply them, for instance, only to its citizens. The area of conflicts of public law, which has up to now been beclouded by the ambiguous slogan of the "territoriality" of public law, still needs a substantial amount of analytical and systematic spadework before we can see more clearly the parallels to, and the deviations from, choice-of-law norms pertaining purely to private law. ${ }^{43}$

\section{The Goal}

The duty of the judge "to do right to all manner of people"44 requires not only that he avoid personal arbitrariness in deciding transnational cases, but also that he shun any attitude suggestive of nationalistic bias. If the judge should attempt to apply the best substantive law after comparing the relative merits of all possible relevant foreign and indigenous legal rules, he will all too readily prefer his own law because he is not trained to appreciate the reasons and the advantages of the rules to be found in foreign legal systems. Therefore, private international law has to be based, in principle, on the equality of foreign and domestic substantive law. Furthermore, the economy of the process of adjudication dictates that the great volume of civil cases be decided according to clear-cut rules without a judicial repetition of the frequently quite involved legislative thought processes; this precludes a weighing of all possibly relevant interests (the situation may be different in criminal litigation or in public international law cases). Consequently, general rules placing limits on justice in individual cases are a necessary element of private law, including choice-of-law rules; if need be, an inequitable result in an individual case has to be accepted so that the stability of the legal order may be preserved. Thus, choice-of-law rules must, instead of selecting that substantive law which has. the "best" rules for the disposition of a particular case, limit themselves to referring to that legal order which, judging by external circumstances, seems most appropriate.

\footnotetext{
"See especially Wengler, Die Anknïpfung des zwingenden Schuldrechts im internationalen Privatrecht, 54 ZEITSCHRIFT FÜR VERGLEICHENDE RECHTSWISSENSCHAFT I68 (r94r); Zweigert, supra note I6; Neumayer, Autonomie de la volonté et dispositions impératives en droit international privé des obligations (2 pts.), 46 Revue critique de droit international Privé 579 (1957); 47 id. 53 (1958).

${ }^{\text {}}$ Franz Gamillscheg has pioneered this field in three incisive parallel studies: Franz GamluscheG, INTERNATIONALES ARBEITSRECHT 7-13, 185-210 (1959); Gamillscheg, Gedanken zu einem System des internationalen Arbeitsrechts, 23 RABELSZ 819 (1958); id., Les principes du droit du travail international, (3 pts.), 50 Revue critiQue de drort international PRIvé 265, 477 and 677 (1961). Two or three studies by other German authors are in the making.

"As provided in the oath sworn by English judges, quoted from Wortley, The Concept of Man in English Private International Law, 33 The Grotius Society, Transactions 147, I54 (1947). (Note by the Editor: the oath formula reads in full: "to do right to all manner of people after the laws and usages of this realm, without fear or favour affection or ill-will.")
} 
(This, incidentally, not only goes for the primary selection of the applicable law, but also for the decision as to which law is to be applied if the contents of the proper law cannot be determined or if it cannot be applied for some other reason; the "Ersatz" law need not necessarily be the lex fori.)

But even this view of choice-of-law rules will not avoid the dangers of nationalistic bias. For instance, a country with a patriarchal family law will regard the choice of the father's personal law as quite natural, while a country where the equality of the sexes has been realized and where the welfare of the child is paramount, may select a different choice-of-law rule. But efforts should be made to avoid such partialities. More particularly, choice-of-law rules should not be tied to the internal constitutional law of the forum state any more than is absolutely necessary. The Institut de Droit international rightly proclaimed the following guideline at its 1952 isession: ${ }^{45}$

The rules of private international law should, generally speaking, use criteria which are capable of internationalisation, i.e., which lend themselves, in particular, to adoption in international conventions, thus avoiding the danger of conflicting solutions of given cases in different countries.

For a different decision of the same case from country to country subjects the reputation of the law and public faith in its inviolability to especially great strains. It is in this sense-and not as a criticism of the multitude of different legal orders as such -that the much cited saying of Blaise Pascal seems justified: ${ }^{40}$

Plaisante justice, qu'une rivière ou une montagne borne!

Vérité au deçà des Pyrénées, erreur au delà.

Furthermore, divergent decisions are often frustrating justified expectations. In the worst cases, there are even conflicts of duties, as when one judgment orders what another judgment forbids (e.g, the performance of a contract despite a moratorium or the outbreak of war, or the restitution of conjugal rights in a marriage recognized in one state but not in another jurisdiction with which the parties also have connections).

The danger of "conflicting solutions of a given case in different countries"-in the most extreme instance, the danger of the abuse of this possibility by "forum shopping" in bad faith-cannot be eliminated merely by procedural rules on international jurisdiction that confer power to decide a particular controversy on the courts of only one state: that state the substantive law of which should be applied (fortm legis). For in many cases, where due to circumstances such as extreme distance, war, and the like, the plaintiff has no access to the courts of such a state, this would lead to a denial of justice; furthermore, the rule would not be practicable for mere preliminary questions. The avoiding of conflicting decisions thus remains as the specific task of choice-of-law rules.

Surely, the complete internationalization of private international law is unattainable in the foreseeable future. All the more is it important that some consideration

${ }^{45} 44$ ANNuAire de L'INstrtut de Droit internatronal pt. 2, at 477 (1952).

20 Blasse Pascal, Pensées no. 108 (Lafuma ed., Paris 1951). 
be given to foreign choice-of-law rules, particularly in cases of renvoi and preliminary questions. In other words, there must be an attempt to achieve "coordination des systèmes." rules free from any predilection in favor of their own substantive law and which attempt to "use criteria which are capable of internationalisation" are tempted to enact rigid choice-of-law rules, and not to make any concessions to less ideal foreign conflicts systems. ${ }^{48}$ But the fact is that there will never be an integral realization of the postulates of justice; and here, too, there is the danger of summum ius, summa iniuria. The optimum attainable is a fair compromise between equity-or what one believes to be equity in the particular case-and legal certainty: between national law and international cooperation.

\section{ConcLusion}

More than a hundred years ago, Friedrich Carl von Savigny wrote in the introduction to his famous treatise on the conflict of laws: $:^{49}$

Germans, Frenchmen, English, and Americans, often stand in marked opposition to one another; but all agree in evincing the most lively interest in the questions which... [this book] embraces, in an effort after approximation and agreement, such as is found in no other department of jurisprudence.

We read these words not without a feeling of shame. For today, even after the heyday of nationalism characteristic of earlier decades has passed, a practical, resigned nationalism or at least regionalism remains dominant. There are especially few contacts between American and continental European private international law, although the relations between our countries are closer than ever before. Part of the explanation for this situation may be found in the fact that in the United States, the international conflict of laws is relatively insignificant as compared to the interstate conflict of laws. The latter is necessarily more limited in scope because the differences between the legal systems of the various states of the American Union are not nearly as great as are those between some national legal systems, and because these differences are, in the main, limited to matters regulated by statute while the remaining portions of private law in the United States still consist of a more or less homogeneous common law. Furthermore, it has to be said in apology for the current state of mutual ignorance that even the best-equipped law library on the European continent cannot subscribe to all American law reviews that publish articles dealing with the conflict of laws, and that European law is relatively inaccessible to Americans, if only for reasons of language. It is to be hoped that the present symposium will increase the contacts between European and American thinking on private international law, thus contributing towards a reciprocal accommodation.

\footnotetext{
${ }^{47}$ This idea of the "coordination des systemes" is especially emphasized by HeNRI Batiffol, TraitE El fMentaire de droit international privé 356-58 (3d ed. 1959), and Henri Batiffol, Aspects PHILOSOPHIQUES DU DROIT INTERNATIONAL PRIVÉ IO2-I4I (1956).

${ }^{48}$ This has already been observed by Melchior, supra note 29 , at $733-34$, with respect to the Italian Civil Code of 1865 . A more recent example is Greek private international law which, while generally refraining from a preference in favor of Greek substantive law, expressly forbids taking into account a foreign renvoi, see Gogos \& Aubin, supra note 19, at 243-46.

"SAvigny, op. cit. supra note 8, at iv; p. 43 of Guthrie's translation.
} 